\title{
The influence of polycystic ovarian syndrome on in vitro fertilization
}

\author{
Victória Brenda Pereira Lopes ${ }^{1}$, Dayane de Medeiros Alves , Deborah de Melo Magalhães-Padilha1* \\ 1Universidade Potiguar (UnP), Natal, RN, Brasil
}

\begin{abstract}
Objectives: The aim of the current article was to review data already published in the literature on Polycystic Ovarian Syndrome associated with infertility. Methods: Search for scientific articles in the databases: Lilacs, SciELO, Medline, Pubmed, Elsevier and Virtual Health Library, from 2001 to 2017, as well as bibliographies present at Potiguar University. Results: Polycystic Ovarian Syndrome is a hormonal disorder that affects a large part of the female population of reproductive age. The main cause of this disorder is hyperandrogenism, which together with oligoanovulation adds more characteristic factors for the diagnosis of this pathology. Hyperandrogenism is characterized by an excessive production of androgen hormones, with this production being discerned by a marked synthesis of testosterone, which is stimulated by the luteinizing hormone and intensified by insulin or by the intrinsic elevation of the secretion of these androgens. Although this pathology is recognized mainly by androgenic elevation, its hormonal action is still unknown. However, studies indicate that the high catabolism of cortisol and the intense response of adrenal androgens to normal adrenocorticotrophic hormone levels are related. Assisted human reproduction (AHR) has been an option to treat infertility due to Polycystic Ovarian Syndrome (PCOS); however it presents, mixed results. Due to the importance of this subject and the absence of recent articles relevant to the topic, the aim of this article was to review the published data on the PCOS associated with infertility. Conclusions: In vitro fertilization is an option to achieve pregnancy in women refractory to treatment with ovulation stimulants. Despite few studies linking Polycystic Ovarian Syndrome with in vitro fertilization, it was found that this biotechnology provides significant results, however it may present subsequent disorders.
\end{abstract}

Keywords: polycystic ovary syndrome; hyperandrogenism; in vitro fertilization; infertility.

\section{Introduction}

Polycystic Ovarian Syndrome (PCOS) is a multifactorial pathology that causes anovulatory cycles, hirsutism, hyper secretion of Luteinizing Hormone (LH), obesity, hyperinsulinemia, diabetes mellitus, amenorrhea, appearance of thick hair and acne in places that depend on the action of androgens, infertility and hyperandrogenism, the latter being the main cause of PCOS. ${ }^{1}$ Given these factors, the quality of life of women with this syndrome is substantially compromised, affecting their well-being and their family and social relationships. Additionally, it decreases self-esteem, especially given the suffering that infertility generates, which increases the prevalence of depression among these women. ${ }^{2}$

In vitro fertilization (IVF) has proven to be an alternative to treat women with PCOS who intend to become pregnant, refractory to treatment with ovulation stimulants. For some authors, the progression of superovulation and IVF treatment in patients with PCOS is similar when compared to women with normal ovaries, with reasonable pregnancy rates. ${ }^{3}$ However, some studies have shown that women with PCOS have a high risk of triggering Ovarian Hyperstimulation Syndrome (OHSS), following ovulation superinduction in IVF, with high rates of cancellation of cycles. Moreover, women with PCOS have a large numbers of oocytes collected, but presenting lower rates of fertilization, cleavage and implantation. Consequently, effective IVF performance would be compromised in women with PCOS, since it expresses a recruitment of a high number of follicles of a reduced diameter, high OHSS rates and reduced fertilization rates. ${ }^{4}$ Despite the significant relevance of PCOS in infertility, there are still few studies correlating PCOS with IVF. Due to this lack, the objective of this review is to describe the interference by PCOS in the assisted fertilization process.

\footnotetext{
Financial support: None.

Conflicts of interest: The authors declare no conflicts of interest.

Submitted: October, 15, 2017.

Accepted: September, 09, 2019.

The study was carried out at Universidade Potiguar (UnP), Natal, RN, Brasil.
}

Copyright Lopes et al. This is an Open Access article distributed under the terms of the Creative Commons Attribution License, which permits unrestricted use, distribution, and reproduction in any medium, provided the original work is properly cited. 


\section{Methods}

This article consisted of a literature review. Satisfying the inclusion criteria, 26 scientific articles were selected from the Lilacs, SciELO, Medline, Pubmed, Elsevier and Virtual Health Library (VHL) databases. The exclusion criteria were articles belonging to languages other than English or Portuguese, and revisions prior to 2001. For the article search, the following keywords were used: polycystic ovarian syndrome (PCOS), hyperandrogenism, in vitro fertilization (IVF) and infertility. It is important to point out that articles in Portuguese and English from 2001 to 2017 were used.

\section{Polycystic Ovarian Syndrome (PCOS) x hyperandrogenism}

The main characteristic of PCOS is exacerbated androgen production, called hyperandrogenism. Being a steroid hormone, androgen is synthesized along with other hormones (adrenocortical and sexual) from cholesterol in various endocrine tissues. Some of these hormones are synthesized in the testicles and ovaries, including Teca and granulosa cells. ${ }^{5}$ Teca cells express the enzyme P450c17, including 17-hydroxylase and 17-20-lyase activities, which are essential for the secretion of testosterone, dehydroespiandrostenedione (DHEA) and androstenedione. Thus, the enzyme P450c17 operates on steroidogenesis defining the class of steroids that will be developed from its precursor. The enzyme P450 aromatase is responsible for the transmutation of androgens into estrogen and acts on the granulosa cells. Any modification in the functions of these enzymes influences SOP etiology. ${ }^{1}$

Cytochrome P-450 enzymes cleave the cholesterol side chain and introduce oxygen atoms by synthesizing the steroids, including androgens. These hormones affect sexual development and behavior, as well as other reproductive and non-reproductive functions. ${ }^{5}$ Hyperandrogenism is an extremely important factor for the diagnosis of PCOS, along with oligoanovulation and micropolictistic ovarian morphology. In particular, the presence of hyperandrogenism and oligoanovulation in these women identifies the classic PCOS phenotype. Therefore, defining this condition has great clinical relevance. ${ }^{6}$

It is important to emphasize that in the diagnosis, the time variation between the onset of the syndrome and the appearance of signs and symptoms influences the polycystic ovarian aspect. ${ }^{7}$ In hyperandrogenism, excessive androgen production is directly related to hyperinsulinemia, because patients with PCOS present insulin resistance. Compensatory hyperinsulinemia stimulates the secretion of ovarian androgen through the Teca cells and reduces SHBG (sex hormone binding globulins) which, in turn, increases androgen dosage, thereby intensifying PCOS symptoms. Additionally, hyperandrogenism is related to the high sympathetic nerve activity in women with the syndrome and the activity of these nerves increasing the response to hyperinsulinemia. ${ }^{8}$ The reduction in fertility rates with an increase in free androgen content (ITA), obtained from total testosterone $\times 100 /$ SHBG calculation in women who have insulin resistance adds to the evidence that insulin resistance increases hyperinsulinemia and vice versa. This may indicate that these factors negatively affect the ovaries and consequently diminish fertility. ${ }^{9}$

In PCOS, the ovaries and adrenal cells contribute to exacerbated androgen production, mainly related to the increase of testosterone, due to the hyper-stimulation of the $\mathrm{LH}$, intensified by the insulin or the intrinsic elevated secretion of these androgens in the Teca cells. Increased adrenal androgen levels have been demonstrated by high dosages of androstenediol, androstenedione, dehydroepiandrosterone sulfate (DHEA) and $11 \beta$-hydroxyandrostenedione (11 $\beta$-OHA). Although there is a strong relationship between the increase of androgen levels and PCOS, its hormonal action has yet to be fully explained. However, it is believed that the high catabolism of cortisol and the intense response of adrenal androgens to normal adrenocorticotrophic hormone (ACTH) levels are associated.7

\section{In vitro fertilization}

Currently, infertility, which is a possible consequence of PCOS, can be reversed using in vitro fertilization (IVF) techniques. IVF is one of the techniques of assisted human reproduction (RHA), and consists of artificial intervention in the natural procreation process, to assist people with problems related to infertility, who wish to achieve motherhood or paternity. RHA is characterized by a set of techniques, such as: artificial insemination and intrauterine and extracorporeal fertilization, which encompass classical IVF and IVF through intracytoplasmic sperm injection (ICSI). ${ }^{10}$

IVF can be divided into five phases: ovulation stimulation; oocyte puncturing; manipulation of gametes; embryo transfer and luteal phase support. Conventional IVF and ICSI have the same procedures, differing only in the manipulation of gametes for the fertilization process. ${ }^{11}$

Ovulation stimulation is performed by pituitary and subsequent ovarian stimulation with decreasing dosages of gonadotrophin (Gonadotrophin releasing hormone - GnRH). Secretion of follicle stimulating hormone (FSH) and luteinizing hormone (LH) are blocked by $\mathrm{GnRH}$ agonists (GnRHa) or $\mathrm{GnRH}$ antagonists (GnRHant). The initial dose is measured according to the natural hormone levels of FSH and the individual's age and can be adjusted throughout the treatment in a step-up and step-down manner. Stimulation cycles are regulated daily through serum estradiol $\left(\mathrm{E}_{2}\right)$ dosages. The 
evaluation of follicular development is performed by measuring the mean diameter of the follicle. Oocyte puncturing is performed when at least two follicles reach> 18-20 mm in diameter, after which human chorionic gonadotrophin (hCG) is administered for oocyte maturation. 34 hours later the oocyte puncture is performed. ${ }^{11}$

Oocyte collection is performed transvaginally using ultrasound guidance. A meticulous vaginal antisepsis is performed and following this, a mild ultracurtic action sedative is administered. Subsequently, with the patient anesthetized, the ovarian follicular puncture is initiated. After aspiration of the follicles, the transducer and the needle are removed, performing a thorough evaluation of the sack bottom, to avoid bleeding. ${ }^{12}$

For the manipulation of the gametes, a small sterile, plastic Petri dish containing the follicular liquid obtained in the laboratory is used. Then, the eggs are identified and classified in relation to maturation. After this, mature oocytes (in metaphase II, with extrusion of the first polar corpuscle) are transferred to a petri dish, which contains previously prepared and stabilized culture medium, remaining until the time of fertilization. ${ }^{11}$ Conventional IVF is performed initially by aspiration, and subsequently by collection of the seminal sample, which is selected by Percoll gradient or swim-up. After the sperm selection, the concentration of this sample is evaluated, verifying the concentration of motile spermatozoa. The final sample is inserted into the mature oocytes, remaining for a period of 16 to 18 hours. ${ }^{11}$

The ICSI is a variation of IVF, which has been indicated for most cases. This choice is justified by the ease of determining the degree of oocyte maturation, followed by removal of the granulosa cells and by a higher rate of fertilization than in classical IVF. The disadvantage of this technique is the cost of the micromanipulation microscope required by the technique. ${ }^{13}$

Given that the causes of infertility are diverse in nature and in both genders, a joint evaluation of the couple is of utmost importance, because the possible cause could be found in either partner. ${ }^{14,15}$ The factors responsible for female infertility include immunological disorders, endometriosis, and ovulatory and structural changes. Additionally, infertility can be influenced by the frequency of sexual intercourse, smoking, age and female body weight. ${ }^{15}$ Cancer treatment also uses IVF techniques for possible alteration of fertility caused by chemotherapy and radiotherapy. ${ }^{16}$ Finally, other infertility causes could be Chlamydia trachomatis (CT) and Neisseria gonorrhoeae (NG) infections. Another factor in recurrent IVF is PCOS, as it is common among women of reproductive age. ${ }^{1}$ The major cause of male infertility is related to problems in spermatogenesis, which may be unknown or genetic, as well as vasectomy and varicocele. ${ }^{17}$

Considering that IVF presents some procedures considered stressful and difficult for both men and women, it is important to emphasize that the emotional factor may affect the final result. ${ }^{18}$

\section{In Vitro Fertilization (IVF) x Polycystic Ovarian Syndrome (PCOS)}

Currently, of the causes of infertility, 30\% are specifically female. However, some studies report that this value may change. ${ }^{15,19}$ Other authors have shown that $40 \%$ of factors leading to infertility are found in men, of which $15 \%$ on average have an unknown cause. ${ }^{20,21}$ Other studies have shown that the female and male factors correspond to $30 \%$ each, with $10 \%$ of these having an unexplained cause..$^{22}$ The causes of infertility linked to the ovaries are equivalent to about 10 to $20 \%$ of infertility in developed countries. ${ }^{23}$

Ovarian Hyperstimulation Syndrome (OHSS) is one of the consequences of PCOS. In PCOS, women develop SHO because polycystic ovaries have several moderately expressed follicles that would be conducive to stimulation, providing a characteristic multifollicular response. The ovarian follicles would be extremely vulnerable to the follicle stimulating hormone (FSH), contributing to the elevation of the receptors due to the increase of the local accumulation of estrogens, causing multifollicular growth together with an elevated accumulation of circulating estrogens. SHO also occurs in women who use IVF, but who do not have PCOS. However, women with the syndrome have a higher incidence, with $7.1 \%$ being severe, $57 \%$ moderate, and $37.5 \%$ mild. In cases of severe OHSS, following ovarian stimulation for intracytoplasmic sperm injection (ICSI) or conventional IVF, the number of oocytes recruited increased, although quality was reduced. Thus, there is a decline in fertilization and implantation rates when contrasted with women who performed ICSI or conventional IVF without presenting SHO.4 On the other hand, studies have reported that pregnancy rates in women with SHO and PCOS and women who did not have OHSS and PCOS were considered equal. ${ }^{3}$

The diagnosis of PCOS by means of polycystic ovarian morphology can be found in $75 \%$ of the patients with the syndrome, however, women considered normal have around $20 \%$ of the same morphological characteristics. Thus, polycystic ovarian morphology cannot be classified as a determinant factor for diagnosis. ${ }^{24}$

Studies have shown that women with PCOS who sought alternatives to IVF treatment were able to recruit high numbers of follicles as well as oocytes after ovarian stimulation, even with decreased FSH levels.4 Another characteristic of IVF results in patients who carry the syndrome is poorly matured, low quality oocytes, which leads to additional complications for fertilization. Recent assisted reproduction techniques, such as the uptake of immature oocytes and subsequent in vitro maturation in patients with PCOS, have been shown to be effective to treat patients with this syndrome. Given this, 
it is imperative that their oocytes show efficiency for maturation and development. This procedure has presented greater advantages than IVF alone, due to its preventing risks from OHSS, low complexity rates in women with PCOS and lower costs. ${ }^{3}$

\section{Conclusion}

Polycystic Ovarian Syndrome (PCOS) is a hormonal disorder that affects 6 to $10 \%$ of women, generally leading to an incapacity for pregnancy. In this literature review, it was found that the performance of In Vitro Fertilization (IVF) treatment in patients with PCOS can lead to secondary problems arising from the steps of the procedure, ranging from emotional to hormonal factors, such as depression, stress, frustration, as well as Ovarian Hyperstimulation Syndrome (OHSS) and hyperandrogenism. Given that most patients with the syndrome may present a high rate of OHSS, follicles with decreased diameters and lower fertilization rates, it was concluded that assisted reproduction techniques are an alternative route for these women, but presenting diminished performance. These techniques, using in vitro maturation of immature oocytes followed by IVF, have been improved to minimize negative consequences and increase satisfaction with the treatment.

\section{References}

1. Resende LOT, Reis RM, Ferriani RA, Vireque AA, Santana LF, Silva ACJSR, et al. Concentração dos hormônios esteroides no fluido folicular de folículos ovarianos maduros e imaturos de pacientes com síndrome dos ovários policísticos submetidas à fertilização in vitro. Rev Bras Ginecol Obstet. 2010;32(9):447-53. http://dx.doi.org/10.1590/S0100-72032010000900006. PMid:21271150.

2. Moreira SNT, Sá JCF, Costa EC, Azevedo GD. Qualidade de vida e aspectos psicossociais da síndrome dos ovários policísticos: um estudo quali-quantitativo. UFRN. 2013;35(11):503-10. http://dx.doi.org/10.1590/50100-72032013001100005.

3. Reis RM, Ângelo AG, Romão GS, Santana LF, Moura MD, Ferriani RA. A síndrome dos ovários policísticos pode interferir nos resultados da fertilização in vitro? Rev Bras Ginecol Obstet. 2004;26(9):727-33. http://dx.doi.org/10.1590/S0100-72032004000900009.

4. Santana LF, Ferriani RA, Sá MFS, Reis RM. Tratamento da infertilidade em mulheres com síndrome dos ovários policísticos. Rev Bras Ginecol Obstet. 2008;30(4):203-9. http://dx.doi.org/10.1590/S0100-72032008000400008.

5. Gonzalez FH, Ceroni SS. Introdução à bioquímica hormonal. 2. ed. Porto Alegre: Editora da UFRGS; 2006.p. 251-312.

6. Tosi F, Fiers T, Kaufman J-M, Dall'Alda M, Moretta R, Giagulli VA, et al. Implications of androgen assay accuracy in the phenotyping of women with polycystic ovary syndrome. J Clin Endocrinol Metab. 2016;101(2):610-8. http://dx.doi.org/10.1210/jc.2015-2807. PMid:26695861.

7. Soares JM JR, Baracat EC. O emprego dos contraceptivos orais combinados na síndrome dos ovários policísticos. Rev Bras Ginecol Obstet. 2010;32:118-25.

8. Stener-Victorin E, Maliqueo H, Soligo H, Protto V, Manni G, Jerlhag E, et al. Changes in HbA1c and circulating and adipose tissue androgen levels in overweight-obese women with polycystic ovary syndrome in response to eletroacupunture. Obes Sci Pract. 2016;4(4):426-35. http://dx.doi.org/10.1002/osp4.78. PMid:28090348.

9. Sathyapalan T, Dickerson EH, Maguiness SM, Robinson J, Dakroury YHZ, Atkin SL. Androstenedione and testosterone levels correlate with in vitro fertilization rates in insulin-resistant women. BMJ Open Diabetes Res Care. 2017;5(1):1-4. http://dx.doi. org/10.1136/bmjdrc-2017-000387. PMid:28761656.

10. Freitas M, Siqueira AAF, Segre CAM. Avanços em reprodução assistida. Rev Bras Crescimento Desenvolv Hum. 2008;18:93-7.

11. Abdelmassih R. Aspectos gerais da reprodução assistida. Rev Bioet. 2001;9:15-24.

12. Dzki A, Pereira DHM, Freitas GC, Cavagna M, Amaral WN. Atlas de Reprodução Humana. São Paulo: Segmento Farma; 2012.

13. Busso NE, Busso CE, Tso LO, Auge APF, Busso RE, Boaro L, et al. Fertilização in vitro com injeção intracitoplasmática de espermatozóide em ciclos naturais. Rev Bras Ginecol Obstet. 2007;29(7):340-5. http://dx.doi.org/10.1590/S0100-72032007000700003.

14. Aldrighi JM. Endocrinologia ginecológica: aspectos contemporâneos. São Paulo: Atheneu; 2006.

15. Cyrino AP, Schraiber LB. Promoção da saúde e prevenção de doenças: o papel da educação e da comunicação. In: Martins MA, Carrilho FJ, Alves VAF, Castilho EA, Cerri GG, Wen CL, organizadores. Clínica médica. Vol. 3. Barueri: Manole; 2009. p. 470-7.

16. Marinho RM, Rodrigues JK, Lamaita RM, Cota AMM, Wainstein AJA, Wainstein APDL, et al. Preservação da fertilidade em mulheres com câncer: atualização e perspectivas. Rev Med Minas Gerais. 2013;23:510-7.

17. Kussler AP, Coitinho AS. Técnicas de reprodução assistida no tratamento de infertilidade. Rev Bras Anal Clin. 2008;40:313-5.

18. Makuch MY, Filetto JN. Procedimentos de fertilização in vitro: experiência de mulheres e homens. Psicol Estud. 2010;15(4):771-9. http://dx.doi.org/10.1590/S1413-73722010000400013.

19. Bennett LR, Wiweko B, Hinting A, Adnyana IBP, Pangestu M. Indonesian infertility patients' health seeking behaviour and patterns of access to biomedical infertility care: an interviewer administered survey conducted in three clinics. Reprod Health. 2012;9:1-7. http://dx.doi.org/10.1186/1742-4755-9-24. PMid:23020912.

20. Gonçalves J. Avaliação do casal infértil. Rev Port Clin Geral. 2005;21:493-503. 
21. Soligo AGS, Barini R, Carvalho ECC, Annichino-Bizzacchi J. Prevalência dos fatores trombofílicos em mulheres com infertilidade. Rev Bras Ginecol Obstet. 2007;29(5):235-40. http://dx.doi.org/10.1590/S0100-72032007000500003.

22. Passos EP, Almeida ICA, Fagundes PAP. Quando a gravidez não acontece. Porto Alegre: Artmed; 2007.

23. Izzo CR. Infertilidade de causa hormonal para o ginecologista. Soc Bras em Reprodução Humana. 2008;8:1-8.

24. Ferreira JAS, Fernandes CE, Melo NR, Azevedo LH, Peixoto S. Síndrome dos ovários policísticos: uma visão atual. Rev Femina. 2008;36:477-83.

\section{*Correspondence}

Deborah de Melo Magalhães-Padilha

Universidade Potiguar (UnP)

Av. Senador Salgado Filho, 1610, Lagoa Nova

CEP 59056-000, Natal, RN, Brasil

Tel.: +55 (84) 3227-1234

E-mail: dmmvet@hotmail.com

\section{Author information}

VBPL - graduada em Biomedicina pela Universidade Potiguar (UnP). DMA - graduada em Biomedicina pela Universidade Potiguar (UnP). DMMP - doutora em ciências veterinárias pela Universidade Estadual do Ceará em parceria com a Southern Illinois University (EUA); professora da Universidade Potiguar (UnP) e da Universidade Federal do Rio Grande do Norte (UFRN).

\section{Author contributions}

VBPL and DMA were responsible for collecting all data. DMMP was responsible for correcting the full text and translation the text to English language. 